INDEPENDENT JOURNAL OF MANAGEMENT \& PRODUCTION (IJM\&P)

http://www.ijmp.jor.br

v. 11, n. 8, Special Edition ISE, S\&P - May 2020

ISSN: 2236-269X

DOI: 10.14807/ijmp.v11i8.1228

\title{
THE INSTITUTIONALIZATION OF ACCOUNTING: THE IMPACT OF NATIONAL STANDARDS ON THE DEVELOPMENT OF ECONOMIES
}

\author{
Nataliia Semenyshena \\ Ternopil National Economic University \\ State Agrarian and Engineering University in Podilya, Ukraine \\ E-mail:natviksem@gmail.com.br \\ Nadiya Khorunzhak \\ Ternopil National Economic University, Ukraine \\ E-mail:n.khorunzhak@ukr.net \\ Zenovii-Mykhailo Zadorozhnyi \\ Ternopil National Economic University, Ukraine \\ E-mail: zadoroznuyzenoviy@gmail.com
}

Submission: $12 / 28 / 2019$

Accept: 1/7/2020

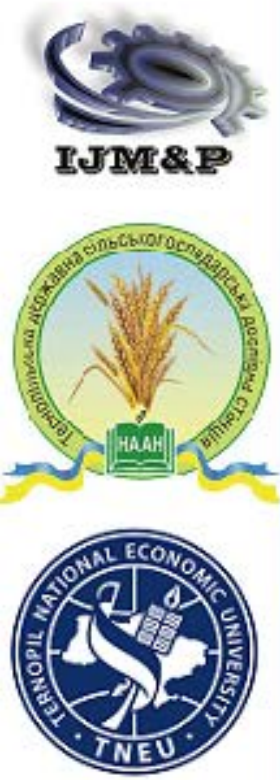

\section{ABSTRACT}

The purpose of the study is to establish the essence and identification of the components of institutional accounting theory and substantiate the role and impact of these components on the national economy through the example of standardization. The author's general scheme of the institutional paradigm of institutional accounting and the approach to the development of his theory was built in the study based on a theoretical, empirical generalization, taking into account positive foreign experience, national scientific views and traditions. The examples of changes in GDP after the introduction of accounting standards (which are a structural component of institutional accounting theory) in the 8 largest countries of the world are given as an argument for the positive impact of institutional pragmatics on the national economy using the graphical method. It is proved that the dynamics that can be used to identify the impact of accounting standardization on a country's economy may be the dynamics of its GDP. The expediency of taking into account the institutional environment of Ukraine in the issues of formalization of the Institute of Accounting, as well as its political, environmental and social situation is substantiated. The conducted research confirms the influence of national peculiarities on the results of activation of institutional accounting principles and the presence of individual characteristics of values taken as arguments of indicators. 
DOI: 10.14807/ijmp.v11i8.1228

It is substantiated that it is important to find effective indicators to illustrate the impact of each institutional component of accounting on the national economy.

Keywords: institutionalization; accounting; institute; accounting standards.

\section{INTRODUCTION}

Modern economic transformations and challenges are changing the attitude of the individual and society to the accounting system and its role in the activities of economic entities. The reasons for this are a number of factors. They are external and internal, weighty and less weighty. But in complex interaction, these factors not only objectively affect the accounting system. They lead to its radical restructuring and change. And it is not just about the structural organization of accounting. The information content and digital interpretation of the data generated by this unique system is of particular importance.

It has long been known that information produced by the accounting system has long been used to substantiate management decisions. The accounting system, without exaggeration, is the information base that encourages one or another decision. This is especially true when it comes to world economic development. The main benefit of a quality accounting system is the promotion of investment attractiveness, which leads to economic growth. This is explained by a number of clearly identified and described in the scientific literature the results of the impact of this system on world and national economic processes.

Accounting is mega important for the economy, and therefore its improvement is a topical area of scientific research. There are a number of factors involved in the need to continue research and find ways to achieve quality accounting improvements. The most significant of these are the change in managerial inquiries that results from the genesis of economic systems, globalization, which requires standardization and unification of accounting, as well as the development of accounting national and international institutions that shape its current conceptual framework.

\section{LITERATURE REVIEW}

The globalization of the economy, inherent in the modern stage of human development, imposes its imprint on all important spheres of its life. There is no exception to accounting, which is one of the most important management functions. In the most general form, the changes occurring in the accounting system are reflected in its targets and implemented through appropriate transformation processes. The latter not only affect the methodology of accounting data, but also lead to more dramatic and significant transformations. 
DOI: 10.14807/ijmp.v11i8.1228

Obviously, accounting in the current economic environment as a system, practice activity or a process is not enough, because it is institutionalized, manifested in the form of characteristic properties inherent in social and economic institutions and institutional business discourse. In recent years there has been a growing scientific interest in accounting as a social phenomenon and a specific type of communication between institutional units (professional, social groups, authorities). It is necessary to examine essence of accounting through the lens of institutionalism in order to identify it in such a plane.

We have to admit that Ukrainian accounting science institutional framework began to be studied recently. However, the theory and concept of the institute in world science has a long history. In particular, this trend has developed in jurisprudence since ancient Rome. Later, in the appropriate adaptive form in the Middle Ages, it was used in sociology and the doctrines of the state. The scientific description of this phenomenon (including that of economics and accounting as its important attribute) is probably made for the first time in T. Veblen's scholarly monograph on the institutional approach to the study of society and economics, The Theory of Leisure Class (VEBLEN, 1912).

Later, this direction was developed by North (2013), who understood that the institute is the limitation created by man, the "rules of the game" in society, which structure political, economic and social interaction. These constraints create formal and informal rules, mechanisms to enforce them, and norms of behaviour (NORTH, 1993).

In the future, virtually all economists-researchers set themselves the task of giving the most complete definition of the concept of "institute", but each of them focused on one of the most important side of the definition. Therefore, the "institute" was considered as: a form of thinking, a system of ideas and volitional manifestations; expectations, customs, behaviours; a set of rules and regulations, etc. (GLOTOV, 2003).

An analysis of the available literature sources on institutional accounting principles suggests that many Ukrainian authors have expressed the view that an active component in this field is an institutional component. That is, they include the determination of the degree of influence of external and internal factors on the possibility of realization of a project into the tasks of accounting.

Another example of subjective consideration of institutionalism in the economy is the proposal to apply institutional accounting theory to management accounting practices (VAILATTI; ROSA; VICENTE, 2016). This approach is also based on the application of 
DOI: 10.14807/ijmp.v11i8.1228

institutional analysis methods to evaluate alternative development models, as it provides guidance on the impact of external and internal factors on an entity's activities.

It is often found that institutional theory is used $\mathrm{n}$ the literature as the theoretical framework to explain the development and application of accounting. It becomes easier to understand accounting as a social and political activity by means of these studies within itself and thus to be able to understand the economic, institutional, political and social environment of the turnover of the practices (particularly in the public sector) (ALDEMIR; UYSAL, 2017).

Relevant factors and institutional constituents of the accounting system are established and investigated on this basis, their impact on economic indicators is substantiated, the place of each of them in the management system is determined.

Scientific discussions related to positioning the place and role of accounting in contemporary economic development often move into the institutional line. Scholars denying the exclusivity of accounting as a system that not only develops itself but also contributes to the development of national economies (PUSHKAR, 2007) argue that it does not have features of self-development. In their opinion, a traditional accounting system is a system that only reflects an already accomplished economic activity (operation, process) that can no longer be influenced.

Scholars who consider accounting as a system that is the basis of information and the basis for strategic development make their case for not only self-development but also expansion accounting functions, tasks and powers (KANTSUROV, 2013; KHORUNZHAK; BENKO, 2002; SOPKO, 2012).

At the same time, both the first and second researchers emphasize the need for the development of accounting theory, given the emergence of new accounting objects, its globalization, the development of institutions and the importance of this type of professional activity.

In the present day world accounting has become a significant social and business institution and its development in this capacity requires a brand new theory. The height of the up-to-date economic thought is the institutional theory (ZHUK, 2013).

The relevant factors and institutional constituents of the accounting system are established and investigated on this basis in Ukrainian accounting science, their impact on economic indicators is substantiated, the place of each of them in the management system is determined. 
ISSN: $2236-269 X$

DOI: 10.14807/ijmp.v11i8.1228

\section{DATA AND METHODOLOGY}

Institutional changes that have engulfed the global economy have certainly affected Ukraine as well. The focus on European integration and the expansion of international cooperation have left their mark on the economy of the country and, at the same time and have led to a series of political events. In this context, innovations that have been introduced to the accounting system and implemented over the past twenty years in the neoliberal policy context have led to the fact that the Ukrainian accounting system, despite its radical reform, does not live up to the aspirations of institutional players.

There are various reasons for this, but the lack of an unified concept and understanding of accounting as an exceptional phenomenon with institutional foundations has a significant impact on such processes. For a long historical period, accounting has been decided as a source of information for management decisions. All of these were usually about ensuring the effectiveness of the entity's activities. Moreover, they are concerned mainly with internal processes that took place at the enterprise.

That is, a narrowed-down approach to defining accounting, for which it is largely regarded as a system that serves to control the use of resources, pay taxes and manage the production process, has prevailed.

But it should be noted that the performance of the modern economy depends more on the evolution of mankind, rather than on the patterns that occur in a single economic entity or even in the national economy.

At this stage of development, the decline of the role of wealth and the increase of the role of symbols (paper money and securities), i.e., the structure of the resource provision is being followed. Particular attention is paid to the traditions, which are a special form of transmission of information about rules of conduct that are passed down from generation to generation. The influence of the external economic environment, orientation of a particular country on certain values or examples is always active.

In spite of the need and importance of the internal levers of self-realization in the issues of accounting development as the basic basis of stability of the national economy, the interests of humanity are at the forefront of global society. The achievement of the latter is largely determined by the political component, as well as the position of the state in the international economic market. 
DOI: $10.14807 /$ ijmp.v11i8.1228

Not all countries have strategically important resource reserves to be active political players, which can influence their own social and political status, to be protected from external international interference (including in internal affairs). In this regard, each country should actively use its own self-implementation mechanisms, including in such an important area of activity as accounting.

Processes of institutional change take place on the basis of self-realization mechanisms, which take place continuously. The accounting system in the field of institutionalism should be considered as an economic institution that is constantly evolving and is a system of theoretical, methodological and practical concepts of forming information about the activity of an entity. It is possible to identify the main elements and build a scheme of the overall institutional accounting paradigm that is implemented in Ukraine based on a critical assessment of the theoretical concepts of Ukrainian scientists, current accounting practices and the state of development of institutional components of accounting (Figure 1).

In accordance with the above paradigm, as well as the conclusions obtained on the basis of a critical analysis of scientific publications of Ukrainian and foreign authors, we can say that in recent years Ukraine has been focusing on improving the accounting system, which is based on the position of its new philosophy (Figure 2).

Social institutions are based on the so-called "rules of the game", which are the centre of institutional theory that originated in the late nineteenth and early twentieth centuries in the writings of North (1993), Veblen (1912), and other well-known foreign scholars. In Ukraine, the state, which is the highest institution for coordination of institutional relations, which forms universal "rules of the game" and creates a base that is expected to balance the competitive environment, is the guarantor of compliance with these rules. 
ISSN : 2236-269X

DOI: 10.14807/ijmp.v11i8.1228

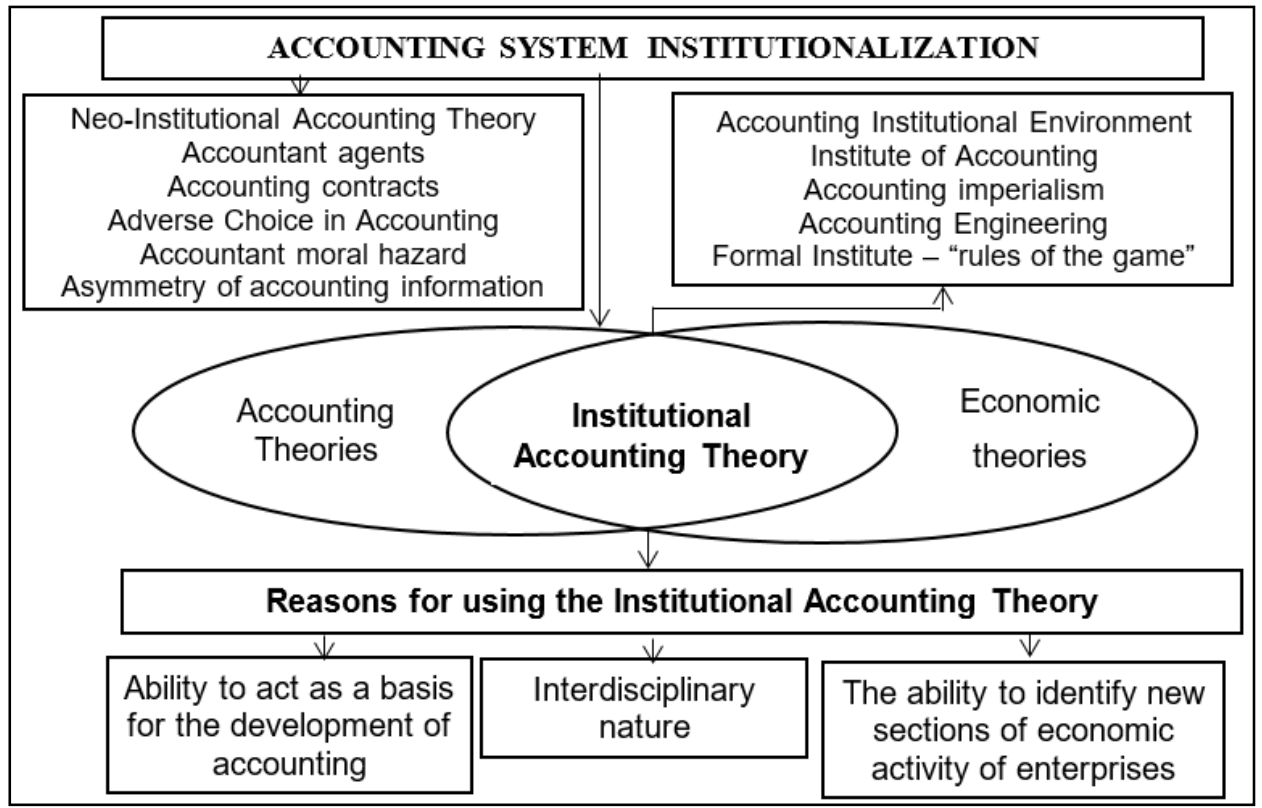

Figure 1: General Institutional Accounting Paradigm Source: independently developed by Nataliia Semenyshena

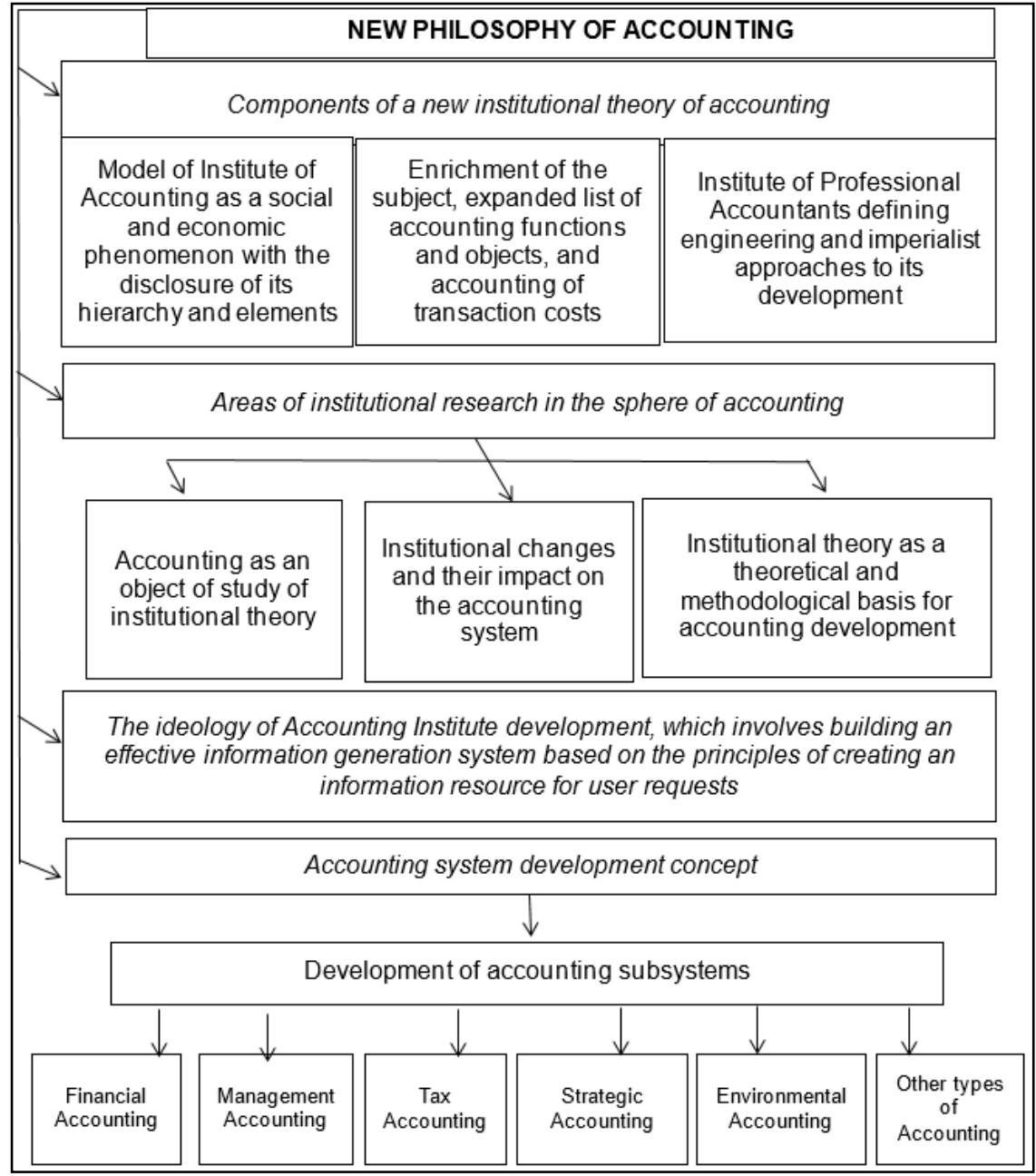

Figure 2: Institutional approach to the development of accounting theory Source: it is developed by Nataliia Semenyshena 
ISSN: $2236-269 X$

DOI: 10.14807/ijmp.v11i8.1228

\section{RESULTS AND DISCUSSIONS}

The two main regulatory levels of the standards that determine the structure, organization, methodology and techniques of accounting in the states are the Law of Ukraine “On Accounting and Financial Reporting in Ukraine” (1996) and the national accounting standards, which are presented for two sub-sectors of the Ukrainian economy: production and public sector economy.

The decision to standardize accounting is likely to be made in Ukraine for several reasons.

The first of these is the globalization of the economy and the orientation of the state towards European integration.

The second is the interest in creating reliable and comprehensible reports, which is the basis for the growth of investment attractiveness of the Ukrainian economy.

We believe that another reason for the standardization of accounting, which is unrepresented and poorly researched, is economic development indicators that confirm the appropriateness of such unification.

It should be noted that in the manufacturing sector and in the public sector, Ukrainian standards have been formed on the basis of maximum consideration of the requirements of international financial reporting standards.

To confirm, we have analysed the dynamics of GDP in several countries after adopting accounting standards. It is worth acknowledging that as a benchmark of such a plan may be the amount of profit received, the amount of taxes paid to the budget, the number of economic entities in the country, and a number of other important economic indicators.

We have chosen the subject for investigation GDP as the most common and publicly state indicator growth.

Everyone knows that the specific and important regulations that characterize accounting and form its basis in most countries of the world are accounting standards. It should be noted that the standardization of accounting in different countries is carried out in two ways:

1) through the adoption of national standards based on IFRS;

2) through the legislative consolidation of the adoption of IFRS as the main regulators of accounting by a separate state. 
ISSN : 2236-269X

DOI: 10.14807/ijmp.v11i8.1228

- So, example 1: Australia.

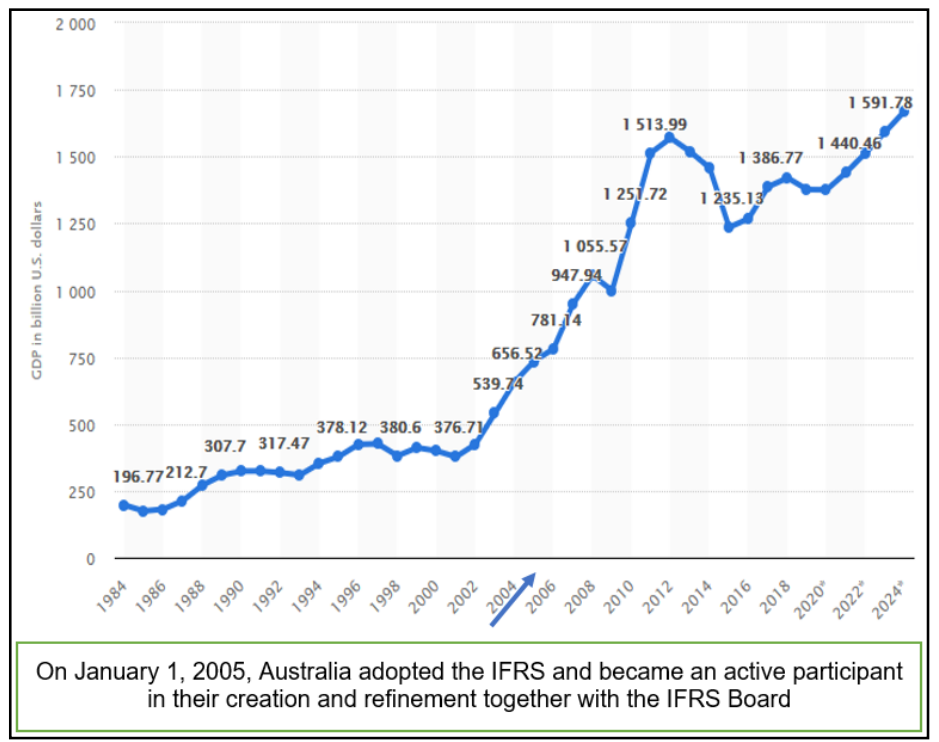

Figure 3: Australia: Gross Domestic Product (GDP) in current prices from 1984 to 2024 * (in billion US dollars)

Source: https://www.statista.com/statistics/263573/gross-domestic-product-gdp-of-australia/

- Example 2: Brazil.

In Brazil, Corporate Law 11,638, which was adopted in 2007 and came into force in 2008, requires all Brazilian companies to prepare their financial statements in accordance with a new set of local standards now issued and based on IFRSs.

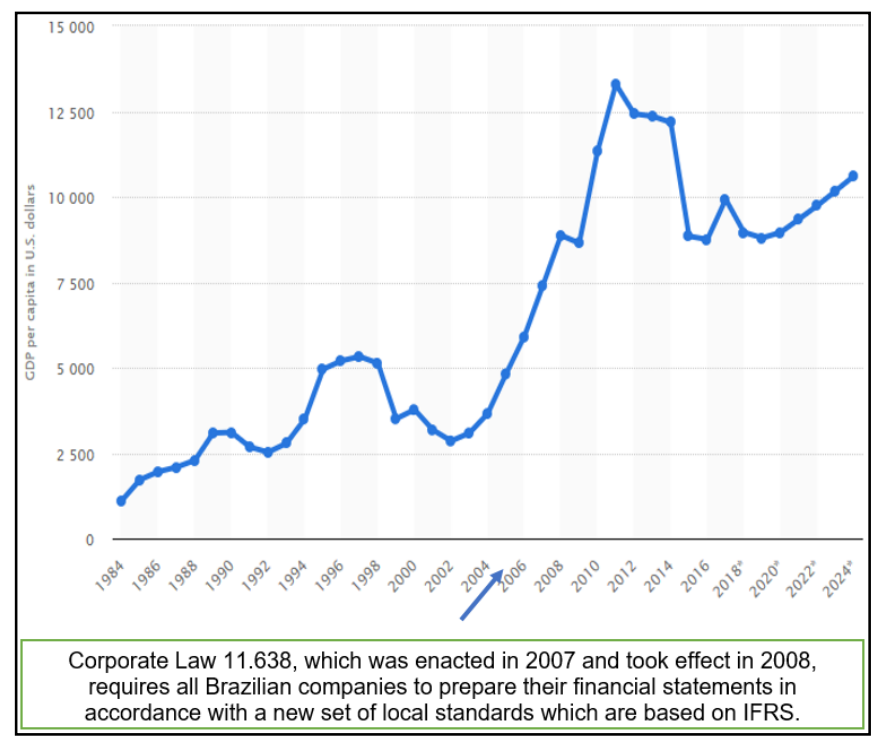

Figure 4: Brazil: Gross Domestic Product (GDP) per capita in current prices from 1984 to 2018 (in U.S. dollars)

Source: https://www.statista.com/statistics/263769/gross-domestic-product-gdp-in-brazil/

- Example 3: Canada. 
ISSN: 2236-269X

DOI: 10.14807/ijmp.v11i8.1228

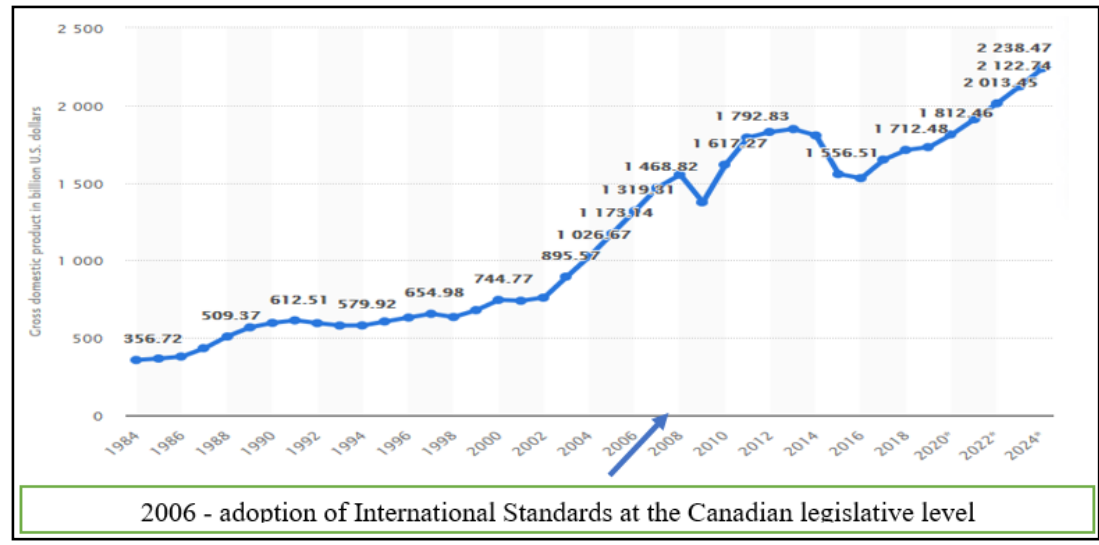

Figure 5: Canada: Gross Domestic Product (GDP) in current prices from 1984 to 2024 (in billion U.S. dollars)

Source: https://www.statista.com/statistics/263574/gross-domestic-product-gdp-in-canada/

- Example 4: France.

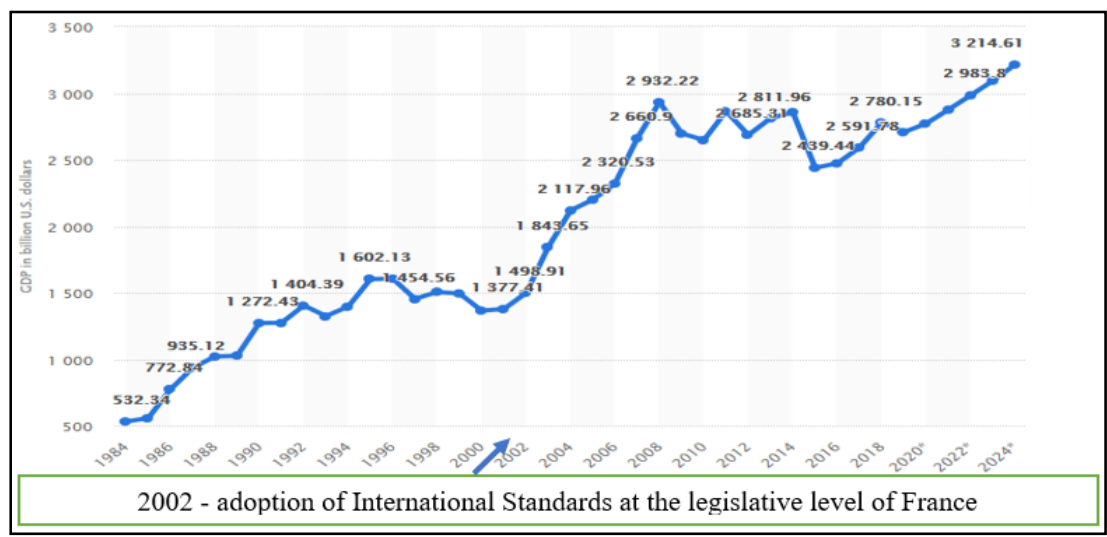

Figure 6. France: Gross Domestic Product (GDP) in current prices from 1984 to 2024 (in billion U.S. dollars)

Source: https://www.statista.com/statistics/263575/gross-domestic-product-gdp-in-france/

- Example 5: India.

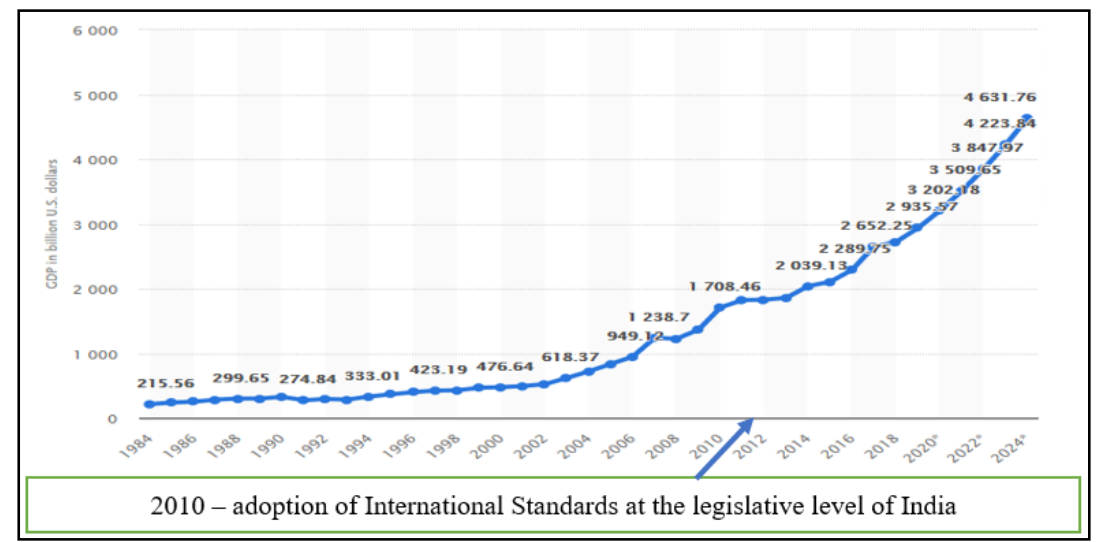

Figure 7: India: Gross domestic product (GDP) in current prices from 1984 to 2024 (in billion US dollars)

Source: https://www.statista.com/statistics/263771/gross-domestic-product-gdp-in-india/

- Example 6: Russia. 
ISSN: 2236-269X

DOI: 10.14807/ijmp.v11i8.1228

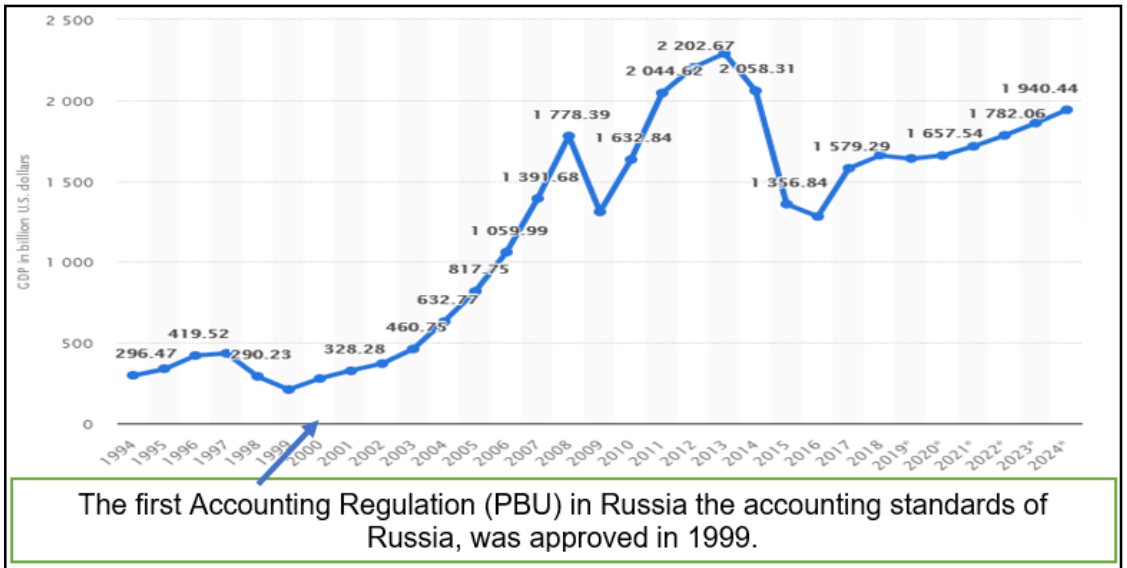

Figure 8: Russia: Gross Domestic Product (GDP) in current prices from 1994 to 2024 (in billion US dollars)

Source: https://www.statista.com/statistics/263772/gross-domestic-product-gdp-in-russia/

- Example 7: China

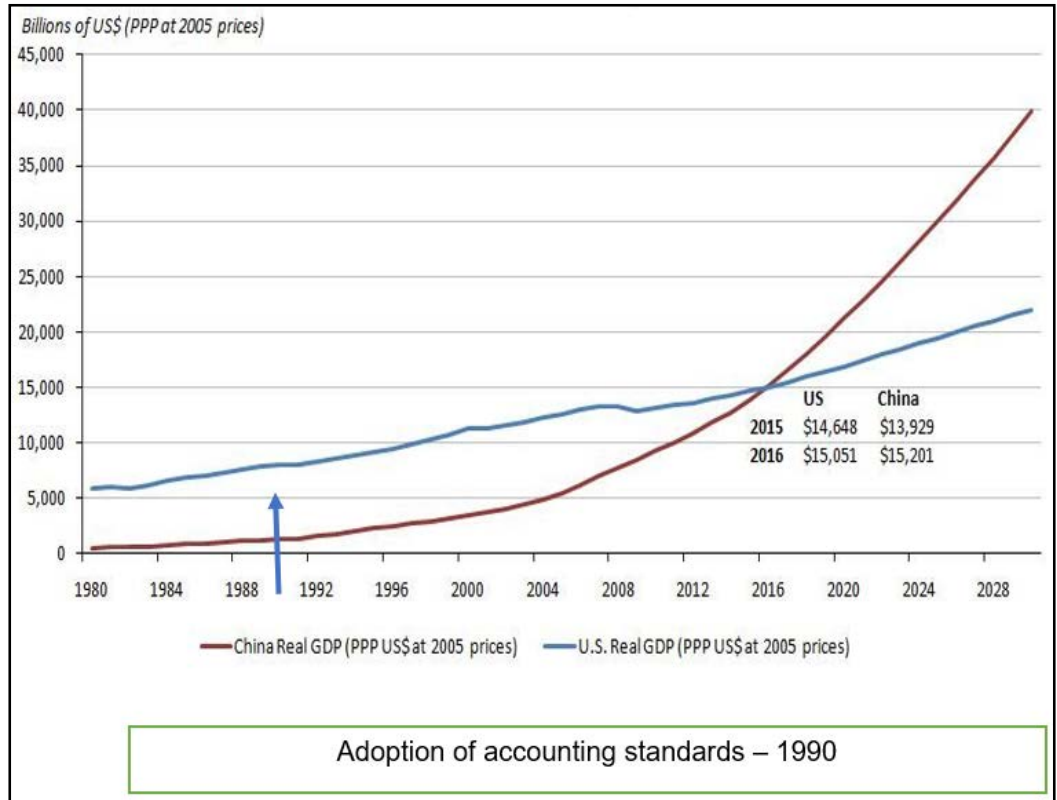

Figure 9: Real GDP, China and the U.S real GDP, 1980-2030

Source: https://i.pinimg.com/originals/74/0d/9c/740d9ccdc7850d4c0bbc95d4fc1b867f.jpg and https://www.statista.com/statistics/263770/gross-domestic-product-gdp-of-china/

Example 8: A country that topped the ranking of the best countries for doing business, compiled by Forbes magazine - New Zealand.

This year, it topped the rating thanks to a transparent and stable business climate that encourages entrepreneurship (Figure 10). 
DOI: 10.14807/ijmp.v11i8.1228

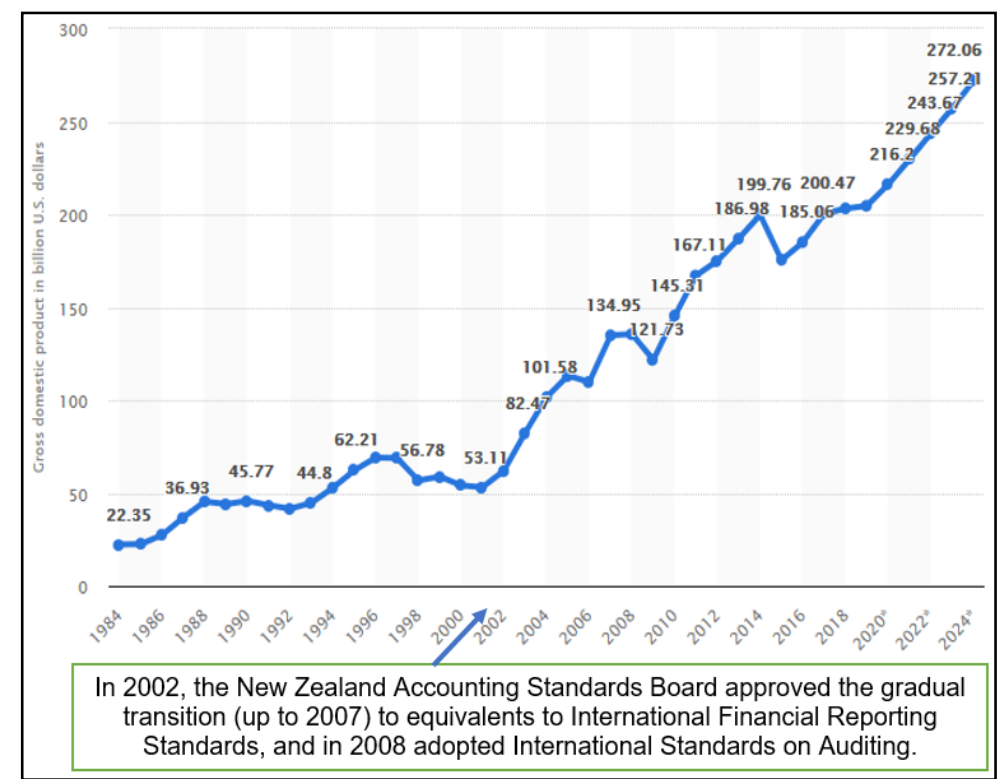

Figure 10: New Zealand: Gross Domestic Product (GDP) in current prices from 1984 to 2024 (in billion U.S. dollars)

Source:https://www.statista.com/statistics/375263/gross-domestic-product-gdp-in-new-zealand/

Similar indicators can be traced in a number of other countries: Switzerland, Germany, Norway, Sweden, etc.

As for Ukraine, this example is not so vivid that it is an exception rather than the rule (Figure 11 and 12).

But there are reasons for this. Such reasons need to be explored in detail.

The process of transforming the accounting system of Ukraine has begun, it can be said with the approved Program of Accounting Reform December 1, 1998. Ministry of Finance of Ukraine approved the "List of terms and statements and the introduction of regulations (standards) of accounting $(\mathrm{P}(\mathrm{S}) \mathrm{A})$.

On March 31, 1999, by order of the Minister of Finance of Ukraine, the first 5 accounting standards were introduced: $(\mathrm{P}(\mathrm{S}) \mathrm{A}) 1$ "General Requirements for Financial Reporting"; (P(S)A) 2 "Balance"; (P(S)A) 3 "Statement of Financial Results"; (P(S)A) 4 “Statement of Cash Flows”; $\mathrm{P}(\mathrm{P}(\mathrm{S}) \mathrm{A}) 5$ "Report on equity”. 
DOI: 10.14807/ijmp.v11i8.1228

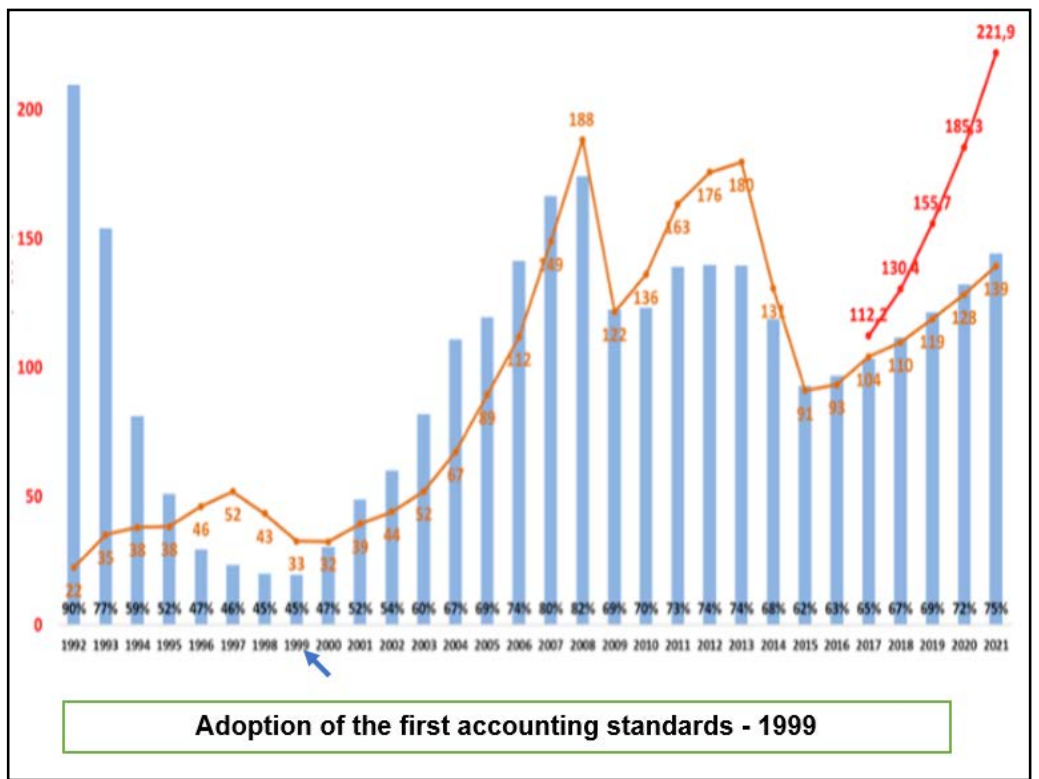

Figure 11: Ukraine: Gross Domestic Product (GDP) from 1984 to 2021 (billion USD)

Note: columns are the ratio of current real GDP to GDP in 1991; broken brown line - \$ billion in GDP USA (2017 forecast); red line - while maintaining the current positive difference between the IMF forecast and actual growth

Source: https://wz.lviv.ua/blogs/368037-dolarovyi-vvp-ukrainy-vyris-za-2017-rik-na-20-5protsent

In 2001, the Audit Chamber of Ukraine adopted the International Standards on Auditing (ISA) as national standards for Ukraine and approved the "Reform of accounting and audit in Ukraine" envisages the development of training programs for IAS and ISA. Ministry of Finance in its action plan to improve financial control in Ukraine, developed by the Cabinet of Ministers of Ukraine has proposed to implement 16 activities to bring the accounting system in accordance with international practice. These measures are included into the introduction of IAS, the revision of the certification program, adoption of best practices, the introduction of ISAs and auditing standards to ensure the introduction of the Audit Chamber and the Union of Auditors.

Thus, the IAS and IFRS are the basis of national regulations (standards) of accounting, however, despite having made significant strides in reforming the accounting system, the state of Ukraine's Institute of Accounting and Reporting in the public administration system is assessed as critical.

The problem is in the imperfection of the constituent elements of the domestic institutional environment and the manifestation of such rules legitimized in the accounting system as coercive isomorphism. In this regard, it should be noted that the policy of the state for accounting can both contribute to its development, and hinder development. In Ukraine, the issue is given low priority - regulation and accounting methodology, until recently, was held 
INDEPENDENT JOURNAL OF MANAGEMENT \& PRODUCTION (IJM\&P)

http://www.ijmp.jor.br

v. 11, n. 8, Special Edition ISE, S\&P - May 2020

ISSN: 2236-269X

DOI: 10.14807/ijmp.v11i8.1228

under the slogan of convergence of national accounting systems with IAS and IFRS, under the "patronage" of foreign consultants and are still not perceived practice.

Among the reasons are: a hasty implementation as a national of international standards of accounting and financial reporting by government agencies to impose the priority of tax accounting and statistical observations of the system of accounting, the removal of sectoral ministries on the formation and control compliance with the methodology of accounting and reporting, which in fact led to a lack State control of compliance with accounting standards, his conduct formal enterprises only to the financial statements of doubtful validity.

In order to clarify how regulatory preconditions accounting realizable in practice, it is necessary to analyze the conceptual framework of the accounting system of Ukraine (Table 1).

Table 1: The conceptual basis of accounting in Ukraine

\begin{tabular}{|c|c|}
\hline The conceptual basis & Accounting \\
\hline Determination & $\begin{array}{l}\text { Process of identifying, measuring, recording, storage, collation, storage and transmission } \\
\text { of information about the activities of the enterprise internal and external users for } \\
\text { decision-making. }\end{array}$ \\
\hline Objectives (tasks) & $\begin{array}{l}\text { Provide full, accurate and unbiased information to internal and external users to make } \\
\text { certain decisions. }\end{array}$ \\
\hline Objects of accounting & for assets, liabilities, equity, revenues, expenses, gains, losses and business-operations. \\
\hline Community Information & $\begin{array}{l}\text { Internal users (managers, owners, participants and property owners of the organization), } \\
\text { external users (investors, creditors, etc.) (Law of Ukraine "On Accounting and Financial } \\
\text { Reporting"). }\end{array}$ \\
\hline Accounting Principles & $\begin{array}{l}\text { - Autonomy } \\
\text { - Historical (actual) cost } \\
\text { - Consistency } \\
\text { - Completeness } \\
\text { - Continuity } \\
\text { - Priority economic substance over legal form } \\
\text { - Charges and the related income and expenses } \\
\text { - Caution } \\
\text { - A single monetary measure. }\end{array}$ \\
\hline $\begin{array}{l}\text { Qualitative } \\
\text { characteristics of } \\
\text { information included in } \\
\text { reports }\end{array}$ & $\begin{array}{l}\text { - clarity } \\
\text { - Relevance } \\
\text { - Reliability } \\
\text { - Comparability. }\end{array}$ \\
\hline $\begin{array}{l}\text { Indicators (elements) of } \\
\text { financial reporting }\end{array}$ & $\begin{array}{l}\text { financial indicators and financial results at the microeconomic level: } \\
\text { - Non-current assets; - Current Assets; - Liabilities; - Capital; - Income; - Expenses. }\end{array}$ \\
\hline Toolkit & $\begin{array}{l}\text { International Financial Reporting Standards, } \\
\text { the Program of Accounting Reform Act of Ukraine "On Accounting and Financial } \\
\text { Reporting, Regulation (standards) of accounting, } \\
\text { strategy implementation of International Financial Reporting Standards, the concept of } \\
\text { accounting systems in the agrarian sector of Ukraine, Guidance, other regulations. }\end{array}$ \\
\hline
\end{tabular}

Analysis of the conceptual framework of accounting in Ukraine can testify that the accounting - accounting system, goals and objectives which are consistent with international standards, it is defined tools and formalized, is available for study, but be aware that it contains, in case of insufficient in-depth study of the conceptual foundations of international accounting 
DOI: 10.14807/ijmp.v11i8.1228

systems, the risks of distortion, incorrect interpretation and undervaluation of information emerging in a particular accounting system.

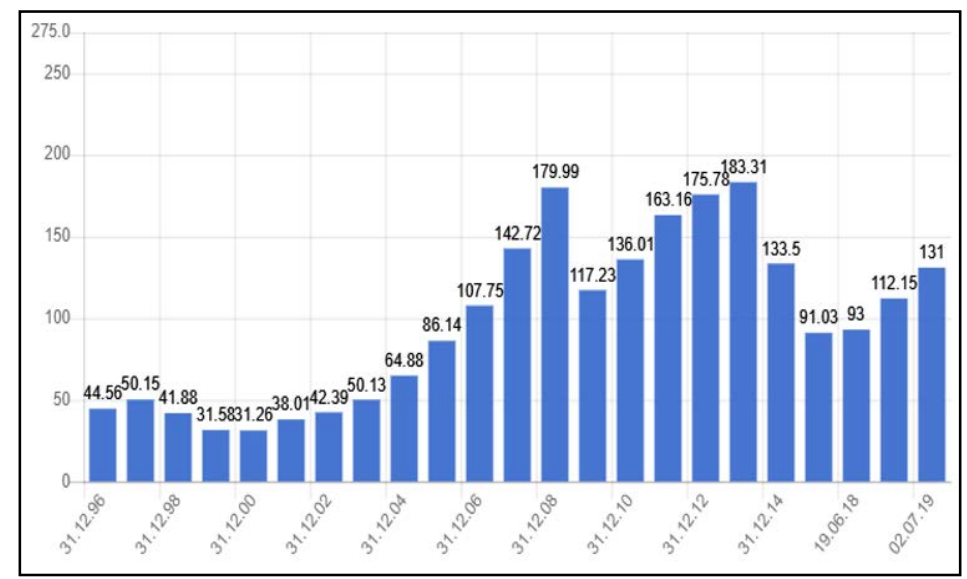

Figure 12: Ukraine: Gross Domestic Product (GDP) from 1984 to 2019 (billion USD) according to the Take-Profit.Org Exchange Portal

Source: https://take-profit.org/statistics/gdp/ukraine/

Later on, new standards were gradually adopted and the old ones improved. One of the most characteristic trends in accounting development in Ukraine is the active promotion of the ideas embodied in international accounting and reporting standards.

Following adoption of national standards (for the manufacturing sector), GDP growth in Ukraine, as in other countries, continued until 2008. After 2008, GDP dynamics were characterized by two recessions, which we associate with the political situation and military action.

In today's accounting school, the development of an institutional approach is relevant, since accounting science in Ukraine was based on principles inherent in the command and administration system, which adversely affected the strategy of its development. Institutional accounting theory combines past experience and current performance, and therefore there is a need to develop fundamental frameworks that allow for identification of identified and potential impact factors and help overcome problems in order to achieve the desired results.

From the above analysis, we can conclude that accounting is an extremely important, specific and integral part of global economic growth, which more dynamically exerts its positive influence when guided by accounting standards. As a significant institutional component, they have an impact on economic development indicators, in particular on GDP.

Regarding the analysed countries and their GDP, we can see some similarity in the fall of GDP after 2012. Although there were no critical crashes, it can be concluded that there were 
INDEPENDENT JOURNAL OF MANAGEMENT \& PRODUCTION (IJM\&P)

http://www.ijmp.jor.br

v. 11, n. 8, Special Edition ISE, S\&P - May 2020

ISSN: 2236-269X

DOI: 10.14807/ijmp.v11i8.1228

manifestations of crisis during this period. The exceptions are India and China, in which GDP has grown steadily and dynamically.

\section{CONCLUSIONS AND RECOMMENDATIONS}

The basis for the development of accounting is institutional support, which allows for the development of programmatic documents and amendments to the Law of Ukraine "On Accounting and Financial Reporting in Ukraine”. Analysing domestic reforms in accounting, we see that today many important points are ignored. In particular, the philosophy of institutional support, which is an indicator of the effectiveness of the national accounting system, is not sufficiently taken into account. Clarification of the institutional paradigm of accounting makes it possible to emphasize the importance of philosophical thinking in it and to form an institutional approach to the development of his theory.

It is clear that to consider the axiom of the arguments given is a rather debatable proposition. However, we believe that the role of standardization in the development of national economies can be proved in this way. More detailed research is needed for more detailed estimates and other factors influencing such an indicator as GDP. It is equally important to substantiate and propose other approaches and criteria for assessing the impact of the institutionalization of accounting (in our case, such component as standardization) on the country's economy.

\section{REFERENCES}

ALDEMIR, C.; UYSAL, T. U. (2017) Public Accounting Reform from Institutional Theory Perspectives: Case of Turkey. Accounting and Corporate Reporting - Today and Tomorrow, Soner Gokten, IntechOpen, DOI: 10.5772/intechopen.68778.

GLOTOV, M. B. (2003) Social'nyj institut: opredelenie, struktura, klassifikacija [Social institute: definition, structure, classification]. Sociological research, n. 10, p. 13-19. (In Russian)

KANTsUROV, O. O. (2013) Udoskonalennia metodolohii doslidzhen bukhhalterskoho obliku. Improving the methodology of Accounting research. In: I International E-Conference Increasing role of accounting in the modern economy (21 February 2013) Proceeding... Kyiv: TOV «Vseukrainskyi instytut prava i otsinky». p. 55-59. Available:

http://188.190.33.55:7980/jspui/bitstream/123456789/2744/1/\%D0\%A0\%D0\%BE\%D0\%BB \%D1\%8C\%20\%D0\%B1.\%D0\%BE.\%2055-59.pdf. Access: 05 September 2019. (in Ukranian)

KHORUNZHAK, N. M.; BENKO, I. D. (2002) Harmonizatsiia ta standartyzatsiia ukrainskoi systemy obliku yak neobkhidna umova efektyvnoho rozvytku vitchyznianoi ekonomiky [Harmonization and standardization of the Ukrainian accounting system as a necessary condition for the effective development of the domestic economy]. In: International Scientific Conference "Bukhhalterskyi oblik ta hospodarskyi kontrol: mynule, suchasne, maibutnie 
INDEPENDENT JOURNAL OF MANAGEMENT \& PRODUCTION (IJM\&P)

http://www.ijmp.jor.br

v. 11, n. 8, Special Edition ISE, S\&P - May 2020

ISSN: 2236-269X

DOI: 10.14807/ijmp.v11i8.1228

[Accounting and economic control: past, present, future. Proceeding...Zhytomyr: ZhITI (in Ukranian)

KUKHAR, M. (2018) Dolarovyi VVP Ukrainy vyris za 2017 rik na 20,5\% [Ukraine's dollar GDP grew by 20.5\% in 2017]. Vysokyi Zamok. Available: https://wz.lviv.ua/blogs/368037dolarovyi-vvp-ukrainy-vyris-za-2017-rik-na-20-5protsent. Access: 05 September 2019. (in Ukranian)

NORT, D. (1993) Economic Performance Through Time. The American Economic Reviw. June 1994, v. 84 n.3, p. 359-368. Available: http://www.wiwi.unimuenster.de/iw/downloads/Im\%20Seminar/ws0708/Literatur\%202/Introductory/Intro3.pdf. Access: 19 August 2019.

PUShKAR, M. S. (2007) Metateoriia obliku abo yakoiu povynna staty teoriia:

monohrafiia [Accounting metatheory or what the theory should be: a monograph]. Ternopil : Kart-blansh. (in Ukranian)

SEMENYSHENA, N. V. (2012) Rasshirenie metodologicheskogo aparata issledovanij v buhgalterskom uchete [Extension of the methodological apparatus of research in accounting]. Buletinul Ştiinţific al Universităţii de Stat «Bogdan Petriceicu Hasdeu» din Cahul ediţie semestrială. seria ŞTIINȚE ECONOMICE, v. 1, n. 7, p. 112-118. Available:

https://ibn.idsi.md/sites/default/files/imag_file/107_112_\%20Rasshirenie\%20metodologiches kogo\%20apparata\%20issledovaniy\%20v\%20buhgalterskom\%20uchete.pdf. Access: 18 September 2019. (in Russian)

SEMENYSHENA, N. V. (2011) Problems of Accounting Reform in Ukraine: Institutional Aspects. In: THE 12TH DOCTORAL CONFERENCE OF FACULTY OF FINANCE AND ACCOUNTING AT UNIVERSITY OF ECONOMICS (27th May 2011), Proceeding..., v I. Prague: Collection of Papers. 2011. P. 277-281.

SEMENYSHENA, N.V. (2012) Institutional analysis of accounting problems in Ukraine. In: MATERIAŁY VIII MIĘDZYNARODOWEJ NAUKOWI-PRAKTYCZNEJ KONFERENCJI «EUROPEJSKA NAUKA XXI POWIEKĄ 2012», v. 4. Ekonomiczne nauki. Przemyśl: Nauka i studia.

SOPKO, V. V.; SOPKO, V. V. (2012) Accounting - basic tool of state regulatory policies of financial and economic stability and economic development. Scientific papers NaUKMA. Economics, n. 133, p. 115-125. Available:

http://ekmair.ukma.edu.ua/bitstream/handle/123456789/2256/Sopko_Sopko_Bukhhalterskyi_ oblik_bazovyi.pdf?sequence=1. Access: 05 September 2019. (in Ukranian)

VAILATTI, J. L.; ROSA, F. S.; VICENTE E. F. R. (2016) Institutional Theory Applied to Management Accounting: Analysis of theoretical and methodological contribution of international publications occurred in the 2006-2015 period. Revista Catarinense da

Ciência Contábil, v. 16, n. 47. p. 91-104. Available:

http://revista.crcsc.org.br/index.php/CRCSC/article/download/2263/1924. Access: 01 Juli 2019.

VEBLEN, T. (1912) The Theory of the Leisure Class: An Economic Study of Institutions. 2-nd ed. Available: http://www.gutenberg.org/files/833/833-h/833-h.htm. Access: 12 July 2019.

ZHUK, V. (2013) Scientific Grounds for Brand New Institutional Accounting Theory.

Accounting and Finance, n. 3, p. 29-34. (in Ukranian) 